\title{
ANALISIS MOTIVASI TENAGA KERJA INDONESIA (TKI) MELAKUKAN MIGRASI KE KUALA LUMPUR (STUDI KASUS DI KBRI KUALA LUMPUR)
}

\author{
Motivation Analysis of Indonesian Workers (TKI) Migrating to Kuala Lumpur \\ (Case Study at the Embassy of the Republic of Indonesia Kuala Lumpur)
}

\section{Raden Biroum Bernardianto" Anggy Ria Sandita}

Universitas Muhammadiyah Palangkaraya, Palangka Raya, Central Kalimantan, Indonesia

email: a biem@yahoo.com

\begin{abstract}
Abstrak
Penelitian ini bertujuan untuk mendeskripsikan dan menganalisis tentang motivasi Tenaga Kerja Indonesia (TKI) melakukan migrasi ke Kuala Lumpur. Jenis penelitian yang digunakan adalah penelitian kualitatif. penentuan informan pada tahap awal peneliti menggunakan teknik sampling aksidental. Sampling aksidental adalah teknik penentuan sampel berdasarkan kebetulan, yaitu siapa saja yang secara kebetulan bertemu dengan peneliti dapat digunakan sebagai sampel, bila dipandang orang yang kebetulan ditemui itu cocok sebagai sumber data. Dalam penelitian ini peneliti melakukan wawancara terhadap 39 informan. Teknik pengumpulan data adalah dokumentasi, observasi dan wawancara. Hasil penelitian menunjukkan bahwa motivasi Tenaga Kerja Indonesia (TKI) untuk berangkat ke Kuala Lumpur tidak hanya terkait motif sosial-ekonomi seperti tingkat pendapatan TKI yang rendah, lamanya bekerja di Kuala Lumpur, tingkat pendidikan TKI, usia TKI, banyaknya jumlah beban tanggungan keluarga, status perkawinan, jenis kelamin, kemudahan dalam mencari kerja, memiliki suami / keluarga di Kuala Lumpur, transfortasi yang memadai, biaya pendidikan yang murah di Kuala Lumpur. Juga terkait dengan peran Kedutaan Besar Republik Indonesia (KBRI) Kuala Lumpur dalam menangani TKI bermasalah.
\end{abstract}

\begin{abstract}
This study aims to describe and analyze the motivation of Indonesian Workers (TKI) to migrate to Kuala Lumpur. The type of research used is qualitative research. Determination of informants at the initial stage of the researcher using accidental sampling techniques. Accidental sampling is a technique for determining samples based on coincidence, that is, anyone who accidentally meets with a researcher can be used as a sample is viewed by the person who happened to be found to be suitable as a data source. In this study, researchers conducted interviews with 39 informants. Data collection techniques are documentation, observation, and interviews. The results showed that the motivation of Indonesian Workers (TKI) to go to Kuala Lumpur was not only related to socio-economic motives such as low income levels of Indonesian migrant workers, length of employment in migrant workers, the age of migrant workers, the number of family dependents, status marriage, gender, ease of finding work, having a husband / family in Kuala Lumpur, adequate transportation, cheap education costs in Kuala Lumpur. Also related to the role of the Indonesian Embassy in Kuala Lumpur in handling troubled migrant workers.
\end{abstract}

\section{PENDAHULUAN}

Telah menjadi fakta yang umum terjadi di Indonesia, rendahnyakualitas hidup, menurunnya lahan garapan dan kebutuhan tingkat pendapatanmendorong masyarakat pedesaan melakukan migrasi. Migrasi yang terjadi dilndonesia terdiri dari transmigrasi, urbanisasi, hingga migrasi Internasional.

Sebagian besar pekerja imigran dari Indonesia memiliki tingkat pendidikan yang rendah dan bekerja di bidang pekerjaan yang tidak membututuhkan keterampilan atau membutuhkan keterampilan rendah. $\mathrm{Hal}$ ini memberikan gambaran bahwa migrasi TKI ke luar negeri berakar pada kemiskinan di daerah asalnya.Beberapa fakta yang umum terjadi di Indonesia yaitu rendahnya kualitas hidup, menurunya lahan garapan dan kebutuhan peningkatan pendapatan mendorong masyarakat pedesaan melakukan migrasi.

Dikutip dari Badan Nasional Penempatan dan Perlindungan Tenaga Kerja Indonesia (BNP2TKI : 20I I) negara tujuan utama migrasi TKI adalah Malaysia 
dan Arab Saudi. Malaysia adalah salah satu negara tetangga terdekatdengan Indonesia. Keputusan untuk menjadi TKI di luar negeri tidak hanya sekedar alternatif melainkan sudah menjadi pilihan dengan segala pertimbangan yang matang.

Di Malaysia, pekerja Indonesia yang legal mencapai sekitar 2,7 juta orang TKI mencari nafkah di Malaysia (Surat Kabar Okezone, 22 November 2016). KBRI Kuala Lumpur mengklaim berdasarkan buku yang diterbitkan, bahwa KBRI Kuala Lumpur sebagai Kedutaan tersibuk di dunia, karena mengurus warga negaranya sekitar 2 juta orang dengan perangkat perwakilan hanya satu KBRI dan $4 \mathrm{KJRI}$. Hal tersebut menandakan bahwa banyaknya Tenaga Kerja Indonesia (TKI) yang memerlukan pelayanan di KBRI.

Tinjauan Tentang Tenaga Kerja Indonesia (TKI)

Tenaga Kerja Indonesia atau disebut dengan TKI adalah setiap warga negara Indonesia yang memenuhi syarat untuk bekerja di luar negeri dalam hubungan kerja untuk jangka waktu tertentu dengan menerima upah. Sedangkan Calon Tenaga Kerja Indonesia atau disebut dengan calon TKI adalah setiap warga negara Indonesia yang memenuhi syarat sebagai pencari 21 kerja yang akan bekerja di luar negeri dan terdaftar di instansi Pemerintah Kabupaten/Kota yang bertanggungjawab di bidang ketenagakerjaan (UU No.39 tahun 2004).

\section{Tinjauan tentang Migrasi Internasional}

Secara umum Lee (1966 dalam Syaukat, 1997

: 24) menyatakan bahwa migrasi merupakan perubahan tempat tinggal yang bersifat permanen maupun semi permanen. Dalam definisi tersebut Lee tidak 23 menjelaskan batasan mengenai jarak, waktu, dan sifatnya perpindahannya.

Dalam definisi tersebut tidak dibedakan secara jelas mengenai perbedaanantara perpindahan antar daerah atau dusun dengan perpindahan antar negara. United Nation (1994) mendefinisikan migrasi sebagai perubahan tempat tinggal dari satu unit geografis tertentu ke unit geografis yang lain.

\section{Konsep Motivasi}

Dalam buku Eveline Siregar dan Hartini Nara (2010:49) motif berasaldari bahasa Latin "movere", yang berarti menggerakan. Menurut Dimyati dan Mujiono (2006:80) dalam motivasi terkandung adanya keinginan yang "mengaktifkan, menggerakan, menyalurkan dan mengarahkan sikap danprilaku individu belajar". Kata motivasi diartikan dari kata motivation yang berarti daya batin atau dorongan.

\section{METODOLOGI}

Dalam penelitian ini penulis menggunakan pendekatan kualitatif dimana dalam penelitian ini dilakukan hanya bersifat deskriptif yang memberikan gambaran tentang permasalahan yang akan diteliti, gejala - gejala sosial, dan fenomena - fenomena sosial. Pendekatan ini digunakankarena sesuai dengan objek dan pokok permasalahan yang akan diteliti yangmemerlukan suatu pengamatan dan pemahaman yang cermat dan seksamaterhadap objek peneliti.

\section{HASIL DAN PEMBAHASAN}

Berikut adalah analisis dari motivasi Tenaga Kerja Indonesia (TKI) melakukan migrasi ke KualaLumpur :

a. Tingkat Pendapatan TKI yang Rendah di Daerah Asal Untuk temuan pertama peneliti menemukan faktor ekonomi

menjadi faktor utama masyarakat Indonesia memilih menjadi TKI dan berangkat ke Kuala Lumpur. Kebutuhan hidup yang harus dipenuhi selalu menjadi faktor masyarakat melakukan migrasi untuk mendapatkan penghasilan yang lebih besar karena keterbelakangan ekonomi yang terjadi di pedesaan akibat sempitnya lapangan pekerjaan. Pendapatan keluarga merupakan salah satu pendorong seseorang untuk bermigrasi. Banyak dari Tenaga Kerja Indonesia (TKI) yang 
berasal dari keluarga dengan tingkat ekonomi menengah ke bawah.

b. Lama Tenaga Kerja Indonesia (TKI) Bermigrasi ke Luar Negeri Lama waktu bermigrasi ke luar negeri pada periode sebelumnyamerupakan salah satu faktor yang turut menentukan pengambilan keputusan seseorang untuk kembali atau tidak kembali bermigrasi ke luarnegeri dan untuk tidak kembali ke Indonesia atau menetap di luar negeri.Pada umumnya para tenaga kerja yang telah melakukan migrasiinternasional pada periode sebelumnya dengan rentang waktu (masakontrak kerja) yang relatif lama akan lebih tertarik untuk kembalibermigrasi daripada mereka yang tidak begitu lama atau belum pernahbermigrasi (bekerja) ke luar negeri sama sekali.

c. Riwayat Pendidikan Terakhir Tenaga Kerja Indonesia (TKI) Pendidikan merupakan salah satu faktor yang mempengaruhi produktivitas seseorang. Walaupun ada faktor - faktor yang turutmempengaruhi seperti status sosial ekonomi keluarga dan motivasi untukmenjadi lebih baik. Namun tidak dapat dipungkiri bahwa pendidikanadalah faktor utama yang menentukan kinerja seseorang.

d. Usia Tenaga Kerja Indonesia (TKI) Dalam hal migrasi umur seseorang dianggap dapat mempengaruhiproduktivitasnya. Sehingga semakin tinggi produktivitas seseorang makaakan mempengaruhi keinginan untuk berpindah ke tempat lain untuk mendapatkan pendapatan yang lebih besar dibandingkan tempat asalnya.Angkatan kerja yang memiliki usia yang lebih muda serta masih berstatus belum menikah cenderung untuk melakukan perpindahan ke-76 daerah lain. Sementara angkatan kerja yang usianya sudah tidak terlalumuda biasanya memilih untuk menetap secara permanen di suatu tempat.
Faktor-Faktor Pendorong Faktor-faktor pendorong atau yang terdapat di daerah asal TKI yaitu tingkat pendapatan yang rendah, lapangan pekerjaan yang sempit, dan banyaknya jumlah anggota keluarga yang menjadi tanggungan. Faktor-faktor penarik atau yang terdapat di tempat tujuan yaitutersedianya lapangan pekerjaan, gaji yang tinggi, biaya pendidikan yangmurah, dan memiliki keluarga / kerabat di Kuala Lumpur.

Kemudian, Faktor penghalang atau faktor yang terletak di antara daerah asal dan daerah tujuan yaitu transportasi yang memadai. Serta, Faktor pribadi atau faktor yang terdapat pada diri seseorang yaituusia TKI, jenis kelamin TKI, status pernikahan TKI, tingkat pendidikanTKI, status pekerjaan TKI di daerah asal, dan lamanya waktu TKI bermigrasi di Kuala Lumpur.

Pemerintah disarankan untuk membuka lapangan pekerjaan seluas luasnya serta dengan menutup atau mengurangi Warga Negara Asing (WNA) yang masuk untuk bekerja di Indonesia. Masyarakat Indonesia saja banyak yang jadi pengangguran, seharusnya pemerintah berupaya untuk mengurangi pengangguran dari dalam negeri, bukan malah menambah jumlah buruh asing yang masuk ke Indonesia.

Wirausaha dalam negeri disarankan supaya jangan terlalu memberatkan syarat-syarat dalam bekerja, jika pekerjaan itu seperti pembantu rumahtangga, penjaga warung, karena banyak ibu-ibu yang berumur lebih dari30 tahun ingin bekerja, tetapi karena syarat-syarat yang sulit untukmereka, sehingga mereka memilih berangkat ke luar negeri

\section{REFERENSI}

Abdullah, Syahfirin. 1996. Faktor-Faktor Penentu Status Migran Penduduk Propinsi Lampung. Thesis Mahasiswa Pasca Sarjana Tidak Dipublikasikan. Jakarta: Pasca Sarjana Universitas Indonesia.

Arsyad, Lincolin. 1999. Ekonomi Pembangunan Edisi Keempat. Yogyakarta: Bagian Penerbit Sekolah Tinggi Ilmu Ekonomi YKPN.

\section{KESIMPULAN}


Bungin, Burhan. 2010. Penelitian Kualitatif, Komunikasi, ekonomi, Kebijakan Publik dan Ilmu Sosial Lainnya. Jakarta : Kencana Predana Media Group.

Dewantara, Anugerah. 2004. Analisis Faktor-faktor yang Mempengaruhi Tingkat Partisipan Angkatan Kerja Wanita. Surakarta : Fakultas Ekonomi UNS Dimyati.

Eveline Siregar dan Hartini Nara. 2010. Teori Belajar dan Pembelajaran. Bogor: Ghalia Indonesia

Hasan, Muhammad,et al. 2002. Metodologi Penelitian Kualitatif, Tinjauan Teoritis dan Praktis. Visipres, Lembaga penelitian Universitas Islam Malang.

Huberman Michael, Miles Matthew and Johnny Saldana. 2014. Qualitative Data Analysis. Arizona State University.- Third edition.

Hugo, J. Graeme. 1978. Population Mobility in West Java.Yogjakarta.

Ida Bagoes Mantra dan Agus Joko Pitoyo. 1998. Kumpulan Beberapa Teori Mobilitas Penduduk. Jogjakarta. Departemen Pendidikan dan Kebudayaan UGM: Fakultas Geografi.

Kartika, Diah Sari. 2003. Analisis Migrasi Masuk Propinsi Jawa Tengah Tahun 2000. Skripsi Mahasiswa S-I Tidak Dipublikasikan. Surakarta: Fakultas Ekonomi UNS.

Kasto. 2002. Mobilitas Penduduk dan Dampaknya Terhadap Pembangunan Daerah: Kumpulan Tulisan Tentang Mobilitas Penduduk IndonesiaTinjauan Lintas Disiplin. Yogyakarta : Pusat Studi Kependudukan dan Kebijakan UGM.

Mujiono. 2006. Belajar dan Pembelajaran. Jakarta : PT. Rineka 